\title{
Traditions synthesis as Fontainebleau styleinternational character foundation in French art of the XVI century
}

\section{La síntesi de tradicions, fonament del caràcter internacional de l'Estil Fontainebleau en l'art francés del segle XVI}

Julia Romanenkova

Kyiv Municipal Academy of Circus and Variety Arts libraryOM@gmail.com

HaLYNA KuZMENKO Institute of Talented Child at National Academy of Educational Sciences of Ukraine glnkuzmenko36@gmail.com

IVAN BRATUS

Borys Grinchenko Kyiv University kulturolog@gmail.com

Olha Konovalova Borys Grinchenko Kyiv University olgakonovalova@i.ua

\begin{abstract}
The article is dedicated to one of the least explored in the art history the art culture of France phenomena in the XVI century - the School of Fontainebleau. The Fontainebleau style stages formation analysis is presented, First and Second Schools founders' creative works main trends are described. First School nature with its dominant Italian traditions as manner foundation, Second School style with its leading northern influence is analyzed. First and Second Schools of Fontainebleau trends comparative analysis was carried out. Italian, French and Flemish traditions synthesis is positioned to be the main School of Fontainebleau style-forming art feature, represented as French local Mannerism version core in the history and art culture.
\end{abstract}

Keywords: Mannerism, traditions synthesis, the School of Fontainebleau, Renaissance, art Italianization

Resum: L'article està dedicat a un dels fenòmens menys estudiats en la història de l'art de la cultura artística de la França del segle XVI: l'escola de Fontainebleau. Es realitza l'anàlisi de les etapes de la formació de l'estil i es descriuen les principals tendències en la creativitat dels fundadors de la Primera i Segona escola. S'analitza el caràcter de la Primera Escola, amb les tradicions italianes dominants i s'analitza l'estil de la Segona escola, amb la seua influència dominant del nord. Es fa, també, una comparació entre ambdues i es veu com la síntesi de les tradicions italiana, francesa i flamenca és la principal característica de formació d'aquest estil considerat la versió local francesa del manierisme.

Paraules clau: manierisme, síntesi de tradicions, escola de Fontainebleau, renaixement, italianització de l'art

DATA PRESENTACIÓ: 12/01/2021 ACCEPTACIÓ: 11/03/2021 ·PUBLICACIÓ: 01/06/2021

SCRIPTA, Revista internacional de literatura i cultura medieval $i$ moderna, núm. 17 / juny 2021 / pp. 86-103 
Julia Romanenkova \& Halyna Kuzmenko \& Ivan Bratus \& Olha Konovalova. Traditions synthesis as Fontainebleau style international character foundation in French art of the XVI century

\section{Introduction}

The XVI century is one of the most contrastive pages of French art history. On the one hand it is the epoch of a new art birth bringing the kingdom out of the post-medieval drowsiness somnambulistic condition. On the other hand it is a multicomponent in its influences intermedia transforming with an unprecedented speed. Stagnation condition was followed by the Renaissance rapid stream of renewal and art Italianization process went through the whole Renaissance from its core to external attributes and became the Mannerism period foundation. France, where new art trends came first of all, became the most devoted student of Mannerist Italy and the French Mannerism style local version became one of the main ones. In the French art culture, which had a rather motley specifity in the XVI century and formed on the basis of Italian, Flemish and local components synthesis, a phenomenon was formed called «The Fontainebleau style» or «The School of Fontainebleau» thanks to the biased Italians of the two waves. The phenomenon had internationality that was lost when the Baroque came. Italian-French and French-Flemish relations led to a unique Italian-French-Flemish culture formation, very specific by its nature with a very rich artistic language, being inclined to complex ideations and no less complicated implementation methods.

«The whales» on which the School rests are the Italian mannerists, who came to Fontainebleau, called «the universal manufactory of Europe» by Francis' I invitation who became not just an art patron of many famous masters but a person who contributed to French art renewal and its speedy still Gothic version transformation into progressive one, brought up on the Renaissant Italy traditions. These were Rosso Fiorentino, Francesco Primaticcio, Niccolo dell'Abbate and following local masters - Antoine Caron, Jean Cousin Sr. and Jean Cousin Jr., creative Clouet dynasty representatives (their creative work is a some kind of "School at School»), later- the Flemings Ambroise Dubois, Martin Freminet, Toussaint Dubreuil. Thereby the School of Fontainebleau main body is international by its nature, combining the Italians, the French and the Flemish. Therefore the School of Fontainebleau special significance should be emphasized to be in context all-European art. After all over the course of time, it was no longer Italy, from where the first Mannerism trends came to the French but that is France, from where the style spread its influence to other lands in the already changed version.

\section{Methodology}

The researches began systematically engaged with the School of Fontainebleau problem in the context of West European art of the XVI century in the 1970s, first of all these were the French. The XVI century art until recent times had been mainly analyzed in the Renaissance heritage context classifying to be late Renaissance and providing with decadent, crisis features. Such works were rarely complex and objective. And only a few decades ago the works where Mannerism took its rightful place in the art history as an independent style began to appear in the art history literature and its 
Julia Romanenkova \& Halyna Kuzmenko \& Ivan Bratus \& Olha Konovalova. Traditions synthesis as Fontainebleau style international character foundation in French art of the XVI century

national variants were re-evaluated and were subject to comparative analysis. Serious researches of J. Ademar, S. Beguin (Béguin, 1960), O. Benesch (Benesch, 1973), L. Dimier, D. Campbell (Campbell, 1990), D. and E. Panofsky (Panofsky, 1992), V. Frienländer (Frienländer, 1957), A. Châstel (Châstel, 1959; Châstel, 1968; Châstel, 1983; Châstel, 1995), J. Ehrmann (Ehrmann, 1986) etc. were published. It became possible in many respects due to art exhibitions that began to be held back in the 1930s. (Fontainebleau e la maniera Italiana. Mostra d'oltremare e del lavoro Italiano nel mondo. Roma, 1952; Fontainebleau. Art in France. 1528-1610. Ottawa, 1973) etc. These events catalogues contain a lot of useful information for phenomenon evolution history understanding.

In the former Soviet Union Mannerism objective re-evaluation process, in particular -its French version- began much later, from the 1990s. The researches dedicated to Mannerism particular local variants including the School of Fontainebleau as the core of the French style version appeared. These are both separate articles and French art history complex works of the XVI century. (Petrusevich, 1973; Romanenkova, 2003a; Romanenkova, 2003b; Romanenkova, 2011 etc.). But the debates regarding the role of Mannerism and its evaluative characteristics exist today.

\section{Results and discussion}

It is quite difficult to clearly define Fontainebleau style period, its chronological framework varies. But the period when being maximally extended can be indicated since the end of XV century to the 30s of XVII one. The First School of Fontainebleau (1530-1570) is associated with the activities of Rosso, Primaticcio, dell'Abbate, Penny, Caron and others but the second one (1594-early 1600s) is represented by the creative works of Dubreuil, Dubois, Freminet, Bunel etc. Most of the outstanding masters are somehow related to the School, so the Fontainebleau became the new style center spreading. There are many almost unknown to researchers masters to this day and the information about them is confined to their names mention in royal counts. B. da Miniato, N. Bellan from Modena (until 1538), C. Bauduen, V. Baron (between 1538 and 1548), A. Banacavallo, F. Cassianemici, M. Roshtel and J. Mousnier, Ruggieri (after 1556), A. Fantuzzi.

What was happening in the castle of the Bievre woodside is called a unique art experiment. This phenomenon formation initial stage was a grand events small model spanning the whole Western Europe. The French monarch converted Fontainebleau into a cultural capital. Each of the European monarchs aimed to attract the most renowned masters to his courtyard, his residence. Granada was

for Charles V, Hampton Court was for Henry VIII, Prague was for Rudolf II, Escorial was for Philippe II and for François I it was his favorite Fontainebleau castle.

The «second wave» Italians arrived to Fontainebleau no longer spontaneously and for a short term, as it was the case with Leonardo or Andrea del Sarto, became actually French Mannerism formation forerunners, they brought with them not only a new iconography but also a different

SCRIPTA, Revista internacional de literatura i cultura medieval i moderna, núm. 17 / juny 2021 / pp. 86-103 ISSN: 2340-4841 · doi:10.7203/SCRIPTA.17.18661 
Julia Romanenkova \& Halyna Kuzmenko \& Ivan Bratus \& Olha Konovalova. Traditions synthesis as Fontainebleau style international character foundation in French art of the XVI century

attitude to religious dogmas, a new subject, genre system particularity, form understanding. France played a very active role in Mannerism diffusion but this process still began at Leonardo da Vinci and his followers period.

Italian masters first wave activity peculiarity at the French court was a short-term stay. Andrea's del Sarto French period was also very short but despite its rapidity today the researchers are not even able to determine either how much exactly it lasted or where precisely Andrea arrived. The Florentine is known to have left for France in 1518 at François' invitation. But there is a piece of information he went to Paris and references he started fulfilling king's commissions in Fontainebleau and Amboise. Andrea came to France in 1518 but how much he stayed there is not exactly determined. He returned in 1519 according to some references. French researches believed the master arrived to France in June 1518 and went already back in October of the following year although there were references to May 1518. The discrepancies can be explained by the fact the new year began on the $25^{\text {th }}$ of March according to the Florentine chronology.

Andrea is known to have painted only two pictures for Francis during his stay at the court, one of which was lost - little dauphin in swaddles portrait and St. Jerome image (has not been preserved). He might have been invited to decorate one of the Amboise castle rooms. Despite such a small number of works the Florentine managed to complete, however it can be said of his significant contribution to the new French art formation because a French children's portrait of the $16^{\text {th }}$ century did not start to develop soon and del Sarto's creation was a kind of forerunner, such phenomenon bringer.

François I, who invited Leonardo da Vinci exactly in 1519, lost both masters and with them - the hope he cherished for the art revival in his state. Since Leonardo died in 1519, having fallen short of king's expectations, Andrea del Sarto remained François' the only chance for the little Italy formation at his court. Del Sarto left the French monarch court for the love of his wife, returned to Florence, having promised to return back soon to France. But he never come back, that is why furious François had not wanted to see any Italians at his court for a long time, so the break between the Italian mannerists waves in France was explained by it.

Zguazella remained and the second del Sarto's follower, Nannochchio, lived in Lyon, while serving for cardinal de Tournon when the master left for France. Zguacella is sometimes identified with Andrea de Antonio di Bartolomeo named as Chiazella, who worked in France in the period of 1516-1524. But this assumption might not be taken clearly because if Zguazella and Chiazella are the same person then it is difficult to understand how he appeared in France two years earlier the master did being del Sarto's follower.

Another of Andrea's del Sarto follower, Francesco Salviati, appeared in France in the middle of 1550s and unfortunately stayed here a while, no more than a year. Although there are different assumptions regarding the dates of his stay: there are references the master came to Dampierre

SCRIPTA, Revista internacional de literatura i cultura medieval i moderna, núm. 17 / juny 2021 / pp. 86-103 ISSN: 2340-4841 · doi:10.7203/SCRIPTA.17.18661 
Julia Romanenkova \& Halyna Kuzmenko \& Ivan Bratus \& Olha Konovalova. Traditions synthesis as Fontainebleau style international character foundation in French art of the XVI century

in 1554, for cardinal de Lorraine service (Romanenkova, 2011), or in 1555-1556, or even 15561557. French period of Salviati is known to have left the castle of Dampierre frescoes preserved in poor condition and the altar image «Bewailing» in St. Margarita Parisian church. The answer to the question whether the master worked in Fontainebleau is also ambiguous. His stay in Paris and Dampierre can be confirmed: Andrea Tarsini invited the master to the French court, he came to Paris and then worked on the frescoes in the castle of Dampierre what is confirmed by the works. But his staying in Fontainebleau has been still only a supposal. At the request of cardinal de Lorraine Salviati frescoed fireplaces cornices and the whole one cabinet in the palace of Dampierre. But despite it he had to go back because he was no longer given commissions - he could not become the king's favorite.

Italian mannerists second wave, appeared at the French court, played a more significant role of the new court social French art formation. All mannerists masters next generation appeared here were at Francis' court for a long time, sometimes they stayed forever. And the Second School of Fontainebleau was already founded under the northern masters influence especially the Dutch ones.

Rosso Fiorentino became one of the second wave first Italians, the Fontainebleau style founders. He came to Fontainebleau thanks to Arethino recommendation and turned into the permanent leader of all artistic processes. He became that figure the School of Fontainebleau history actually begins in its heyday. Rosso Fiorentino brought to France not only his manner. He was the first who did what Leonardo and del Sarto had not been able to do in time because he stayed on the France territory a long enough. In addition to «Pieta» written for the Great Connetable Anne de Montmorency, the only serious work of Rosso Fiorentino preserved in Fontainebleau to this day is the frescoes in king Francis' gallery. The other master's works were lost: works in the Small Gallery, Poets Pavilion, Pomona Pavilion, triumphal structures projects. They can be talked about based only on the copies and engravings. Rosso's graphic was only auxiliary like the other masters' ones of that time. The artist had been engaging in the French art style transformation for ten years. And his style was influenced by N. del'Abbate, L. Tiri, F. Primaticcio in its turn.

Rosso's work on François' I gallery became a landmark both in his creative activity and French art in general. The general Fontainebleau decoration program was realized in it, its frescoes and sculptural decoration the researches call to be one of the earliest and most advanced Mannerism achievements. The sketches were yet prepared by the artist during his stay in Paris. However the work beginning in the gallery was preceded by two more large frescoes creation on the top floor of one of the pavilions in which F. Primaticcio also participated. Documents indicate Rosso's work on Francis' gallery from July 1533 to 1539 . The artist became the all works head that were taking place in the castle at that time in 1536. The artists and artisans guild was working with him. Unfortunately the original gallery appearance is not much known, the frescoes changed, were restored that quickly began after cycle creation. But there are preliminary drawings copies, actual to frescoes painting.

SCRIPTA, Revista internacional de literatura i cultura medieval i moderna, núm. 17 / juny 2021 / pp. 86-103 ISSN: 2340-4841 · doi:10.7203/SCRIPTA.17.18661 
Julia Romanenkova \& Halyna Kuzmenko \& Ivan Bratus \& Olha Konovalova. Traditions synthesis as Fontainebleau style international character foundation in French art of the XVI century

François's gallery combines various innovations numerous examples. Rosso's style founded on Michelangelo's art influence of a developed period was so formed and improved during the work on this gallery that his influence was reflected in the artist's followers style: both Primaticcio and dell'Abbate, and da Modena, and Tiri, and J. Dumonstier adopted it. All these masters had Rosso's «background» but it was not a slavish adherence but only their creative method ground, their thinking direction.

The cycle frescoes subjects were taken from ancient myths and classical authors works but had an unusual representation - in this case innovation also took place. It was Francis' I apotheosis kind, his kingship glory, woven from allegories. However these frescoes iconography final interpretation remains to be an open question as well as who exactly owned the gallery decoration program. A large number of nude bodies were introduced into the designs that previously were found only in those images where it was assumed by the subjects or traditional iconography. Pride, inspired by physical beauty, unfearing nudity display was a completely new phenomenon in France. The decorative styling was also new because painting and sculpture harmonized: each composition was surrounded by a sculptural frame.

The gallery is decorated with 14 frescoes: «A Sacrifice», «The Royal Elephant», «The Burning of Catane», «The Education of Achilles», «Venus scolding Cupid», «The Battle of the Lapithes and the Centaurs», «The Loss of Perpetual Youth», «The Death of Adonis», «Cliobis and Biton», «The Unity of the State», «Ignorance Driven Out», «The shipwreck», «Danae» (this fresco was already painted by F. Primaticcio) and «The Nymph of Fontainebleau» (the last two compositions are the central frescoes of each row located one opposite another). There were two more canvases in the western and eastern parts of the gallery also created by Rosso on mythological subjects - «Venus and Cupid» (at the eastern end) and «Venus and Bacchus» (at the western end).

There are six main frescoes by Rosso's brush on each side and a carved panel below. A mahogany worker de Carpi who worked under Rosso's paintings was invited to perform the ceiling carving and panels ornamentation that reached the middle of the wall. The floor is made of wooden parquet. Murals were conceived to be a complete complex, clearly built cycle. There is a philosophical subtext, an antique subjects with modernity similarity in each allegory. The frescoes are not just ancient myths illustrations but are a kind of illustrated story of Francis I reign. The design could belong both to Rosso or de Baif and to someone else from humanists of that time - to A. Alsiad or G. Bude. The researchers tend to think that namely A. de Baif was if not the author then the co-author of a rather complicated mural program. All compositions are tied by a semantic thread together. This is «Gloria of Francis», his personal valor, merit, anxiety for knowledge antheming. But the artist sings the French state praise the power and strength, its victories. There is Francis' I motto placed above, on each of the 12 frescoes, a salamander in flame with a Latin inscription: «Nutrisco et extingno»- «I nourish and extinguish». Thus the murals also performed a representative function containing admonition. What Rosso embodied in painting, J. du Belle reflected in poetry glorifying 
Julia Romanenkova \& Halyna Kuzmenko \& Ivan Bratus \& Olha Konovalova. Traditions synthesis as Fontainebleau style international character foundation in French art of the XVI century

the king. «The Iliad» and «The Odyssey» by Homer, Herodotus' writings (for the first time in the Western European art), the Apuleius by Valeriy Maxim («The Golden Ass»), («Metamorphoses») by Ovid, («Description of Greece») by Pausanias were the direct literary sources subjects. It is difficult to talk about the frescoes picturesque qualities because they have been seriously changed.

Francesco Primaticcio arrives to François' I court in1531, primarily competing with Rosso and then replacing him there. The master is known to have designed a lot of court festivals, masquerades, balls, decorated many interiors including the Gallery of Love, the Throne Room etc., was engaged in the palace gardens design (Pomona Pavilion). During the period of Henry II he participated in the house of de Guises tomb memorial stone, funerary urn Francis' I heart creation, later he had to deal with Henry's II own memorial stone decoration in the rotunda of Valois in Saint-Denis. The great majority of the works he created (paintings for enamellers and weavers, picturesque canvases sketches for private customers) are either severely damaged or even lost.

Except the famous works in Fontainebleau that became the «new Rome» for European art, several more ones are associated with Primaticcio name. The probable period of one of them (1541-1543) indicates this work possibility creation in the first Roman period. This is the «Holy Family with St. Catherine and John the Baptist» from the Hermitage collection. Originally the work was referred to Parmigianino, then - to Pontormo, later - to Tibaldi and only then it was attributed to Primaticcio. «Ulysses and Penelope» is currently kept at the Toledo Museum of Art, «Self portrait» has found shelter with the Uffizi - the Bolognese's work spread round the world.

«The Rape of Helen» fate is equally interesting. The date of the canvas creation is defined as 15301539. And this makes it possible to assume the author yet began his work in Mantua and finished already in Fontainebleau. This is Primaticcio's one of the very few completed easel works that has survived.

Rosso Primaticcio became a leader of fashion, artistic tastes dictator in Fontainebleau after his death. It was his artistic canon mastery in the First School of Fontainebleau second stage development. Fontainebleau becomes more powerful source of Italian trends spreading in the Northern Europe art. Primaticcio replaced Rosso's emphasized expressivity with slow and languid ceremoniousness. He adhered to Mannerism art main rules, was inclined to the elegant, air figures beauty, the undefined changeable images nature.

The artist's creative work French period can be divided into two stages with some conditionality proportion: before and after his trip to Italy by the king's order. Master's work had a break for a while when he went to his motherland to make copies of the antiques. But unlike A. del Sarto and Cellini he returned. After the king's death Primaticcio stayed away from business for some time because Henry II wanted to see French masters at the court places and the works management passed into the hands of F. de l'Orme. However after Henry's death Primaticcio's importance increased. During the second stage of his stay in France (until 1570) he directed all Fontainebleau paintings, de Valois' tomb construction and its sculptural decoration creation.

SCRIPTA, Revista internacional de literatura i cultura medieval i moderna, núm. 17 / juny 2021 / pp. 86-103 ISSN: 2340-4841 · doi:10.7203/SCRIPTA.17.18661 
Julia Romanenkova \& Halyna Kuzmenko \& Ivan Bratus \& Olha Konovalova. Traditions synthesis as Fontainebleau style international character foundation in French art of the XVI century

Primaticcio made cartoons for the royal embroiderers manufactory, decorated festivals. The Duchess d'Etampe's, François' I the favorite, private rooms, «The Golden Gate» pavilion lobby, the Ulysses gallery and the Ballroom, the Pomona pavilion decorations as well as participating in the Francis' I gallery design were his main creations. Each gallery fresco had a stucco framing. It was ornate, sumptuous elements conglomerate, cartouches, fruits garlands, semi-columns, atlantes, caryatids, putto combination. The figures proportions are extremely outstretched. The sculptural compositions according to their content are not directly related to the frescoes, these are allegorical figures with many attributes, symbolism.

Primaticcio used the help of $\mathrm{N}$. dell'Abbate while Ballroom designing. The hall symbolism is very luxuriant. Here are Henry's II emblems in many interpretations. Almost everywhere they are in weaved with the symbols and initials of his favorite that outraged even his contemporaries Diane's de Poitiers monograms replaced the queen's ones. These are France coats of arms, Order of St. Michael signs, the letter $\mathrm{H}$ (which by the way is sometimes read by researchers as $\mathrm{C}$ as a hint for Catherine de Medici, or as D that returns to Diane de Poitiers), the king and Diana's emblems in the form of a semi-moon (one or surrounded by a group of trees), royal mottos, bow and arrows (they are also the king and madame's de Poitiers emblems).

Primaticcio painted pillars on mythological scenes subjects. The maestro is assumed to have been himself preparatory drawings author but actually dell'Abbate with assistants realized painting works. In 1549 - 1552 F. de l'Orme managed Ballroom decoration works. Primaticcio also realized two bronze statues decorated the fireplace in 1556.

The Duchess d'Etampe's private room and the Ulysses Gallery are interiors that can only be used to judge Primaticcio's craftsmanship with a major part of conditionality. This is explained by the fact the Ulysses Gallery was destroyed in the XVIII century and the Duchess d'Etampe's private room was turned into stair landing. But the upper balcony of the picturesque panels sculptural framing has been preserved. Although the frescoes were almost completely destroyed it is possible to imagine their subject filling according to documents and those details that have survived to our days. The royal favorite's private room decor was dedicated to Alexander the Great's history which Rosso had already addressed to in the Gallery of Françios I. The frescoes stucco framing is full of manneristic, outstretched figures resembling Parmigianino's style at the first glance. Primaticcio's manner inspired a lot of masters - many followers of the Bolognese appeared in France.

In 1552 Niccolo dell'Abbate arrived in France. Together with Primaticcio this artist participated in the Ballroom, the Ulysses Gallery, madame d'Etampe's bedroom decorations. N. dell'Abbate became the landscape new view founder, this genre gets a new role in the art due to him, begins to exist not as an additional element in the other genres compositions but as almost independent one. The works «The Conversion of Saul», «The Finding of Moses» (1555 - 1565), «The Death of Eurydice» (after 1552), «The Rape of Proserpina», «Landscape with Ladies and Horsemen» or «The Stag Hunt » (the mid of the XVI century), «Alcina Meets Ruggiero», «The History of Aristeas» 
Julia Romanenkova \& Halyna Kuzmenko \& Ivan Bratus \& Olha Konovalova. Traditions synthesis as Fontainebleau style international character foundation in French art of the XVI century

can serve as examples. The landscape where the architectural elements are introduced is of great importance in these canvases. The human figures in them have rather the staffage functions.

The picture associated with the name of $\mathrm{N}$. dell'Abbate, that is stored in Budapest Museum of Fine Arts (and its copy - in Vienna), stirs an interest. «The Portrait of Catherine de Medici», most likely painted in 1533, still back in the future Queen of France Italian life period, might have been commissioned on the occasion of Catherine and Prince Henry's betrothal. This work was primarily attributed to Parmigianino, later - to Cavazzoli, and only then was it attributed to master dell'Abbate's period. This is one of the very few portraits of Catherine at a young age - here she is no more than 14 years old and most of the works portray her in the widow dress and is a completely different iconographic type. Niccolo is also known to have painted Henry II and his wife's portraits immediately after his arriving at the king of the French court.

Dell'Abbate was also engaged in decorating court festivals, making cartoons for carpets, drawings for enamellers as evidenced by his ornamental sketches and grotesques, he also resorted to graphic monarchs' glorias, for example, to Charles IX and François II that evidently was a preparative material for the numerous royal triumphs design. The most outstanding noblemen, like constable Anne de Montmorency, were among dell'Abbate's customers. Dell'Abbate's graphic heritage is also very considerable but the master's contribution to the landscape genre development is surely the most significant for French art.

In 1537 (or 1541) Luca Penny appeared in France. This personality is poorly investigated by the scientists, some of his works were engraved and copied by successors and are known only because of it. The works «The Death of Cleopatra», «Mars and Venus», «Jupiter and Antiope» became known in the following way: «The Death of Cleopatra» was saved by engraver and aquaforrtist Rene Boivin for the art treasure house, «Jupiter and Antiope» was reproduced by Jean Mignon, who worked in Fontainebleau between 1537 and 1540, «Mars and Venus» was engraved by an anonymous master.

Researchers write about Francesco Caccianemici only because of his survived paintings created for the embroiderers manufactory. Antonio da Rantuzzi, who came from Trient, was famous for his grotesques and engravings. The Florentine Miniato mentioning let suggest him to have cooperated with Rosso. He is attributed to the panel depicting allegorical figures in the king and queen's private rooms, where Caesar and the Force are painted. Ramenji also worked on these private rooms decor. Andrea Zguazella and Nannochchio who worked in France during that period, were A. del Sarto's followers. Zguazella stayed in France after the master's departure and the second del Sarto's follower Nannochchio lived in Lyon, being in the service of Cardinal de Tournon.

Giacomo Barozzi da Vignola is another surname that is found among those who made a contribution in creating a new style in French art. Unfortunately his French period generally is not illustrated. He is only known to have entered the service of Primaticcio who bought antiques on behalf of 
Julia Romanenkova \& Halyna Kuzmenko \& Ivan Bratus \& Olha Konovalova. Traditions synthesis as Fontainebleau style international character foundation in French art of the XVI century

the French king in Rome and left for Fontainebleau together with him. However it is difficult to establish when it exactly happened, his French period was very short in duration. The architect had been staying in Paris and Fontainebleau for about three years, was acquainted with Primaticcio and Serlio. He is known to have worked together with Primaticcio on François' I commission but this was only one for execution of casts and copies from a number of antiques. And then, according to scientists' evidence, he and Serlio had been creating a new type of the king's residence in Fontainebleau for three years. But his stay in the «Kingdom of Lilies» chronological terms are still not precisely established.

But the Bolognese Sebastiano Serlio had spent 3 years in France, from 1541 to 1554, that is why his Fontainebleau style architectural component development contribution was much more significant. He arrived after his Roman period at the age of 75 years old. His French period was probably even more fruitful than Italian one. Serlio worked a lot on the French territory - in Paris and of course in Fontainebleau. Right from the moment of his appearance at the court, he was involved in the castle of Fontainebleau modernization process. The «Universal Manufactory of Europe», where the main artistic forces were focused had to lick into shape, therefore Francis was engaged in its decoration with great desire. In 1541 the overlooker courtyard large stairs were modernized - nowadays it is socalled Serlio Porch in the Oval Courtyard of the castle. The survived park structures paintings since that time indicate that Serlio was also involved in the pavilions constructions in the Fontainebleau parks. He is assumed to have created the project and built one of the beautiful castles of Burgundy -Tanlay. In 1554 S. Serlio died in Fontainebleau.

Sculptor G. A. Montorsoli staying in France is generally questioned. The documents have not saved anything about his French period, but Vasari gives rather specific references not only to his French court trip, but also to the work on a specific order in his biography. He notes that cardinal de Tournon was looking for royal service sculptor and invited Montorsoli for this role who might have worked then in Rome on Pope Julius' II tomb (along with Michelangelo), although it has also not been confirmed and remains only a hypothesis. The king gave the sculptor a commission to create four large statues Montorsoli started working on, he managed to make models, but during the king absence fell into dispute with the treasurers and decided to leave informing the king. Therefore further he goes to Lyon and from there again to Italy, to Genoa through Provence.

Benedetto Grazzini di Bartolomeo was among the artists who worked for some time in Paris, decorating duke Louis of Orleans and Italian Valentina Visconti's tomb with other Italians in 1502.

But B. Cellini made itself more significant contribution to the French art culture. The master worked for the king of the French both as a sculptor and as a jeweller, and as an antiques connoisseur who helped the king to purchase them for his collection. He visited France twice but for the first time -for a very short period. His first visit was explained not so much by Francis' I desire to see him at the court as by master's regular problems with the power players at his motherland from where he had to leave. That is why having received the French king invitation Cellini leaved from Padua for

SCRIPTA, Revista internacional de literatura i cultura medieval i moderna, núm. 17 / juny 2021 / pp. 86-103 ISSN: 2340-4841 · doi:10.7203/SCRIPTA.17.18661 
Julia Romanenkova \& Halyna Kuzmenko \& Ivan Bratus \& Olha Konovalova. Traditions synthesis as Fontainebleau style international character foundation in French art of the XVI century

Francis' court taking with him two followers. In the famous «La vita ...» he describes his meetings with Rosso where he speaks in dispraise of him, with Zguazella. Soon Cellini goes to the «Fontana Bilio» from Paris, then he leaves almost immediately for Rome. Master's first French period was marked only by one cardinal Ferrara's commission to make silver bowl and jug.

Cellini's second stage stay in France began after 1540. The king made at once a commission for 12 silver gods statues in human height, however, only 4 models were made of wax about 16 inches in scale - Juno, Jupiter, Vulcanus and Mars. The statues had to play the role of specific chandelier - to hold torches in their hands (6 statues - in the left hand, 6 - in the right one) in order to illuminate the gallery of Francis I where it was planned to install. It is interesting the statues pedestals had to be fitted to movement - to have wheels so that the statue could be transported to that gallery place where light was needed from time to time (Avery, 2000). It can be found out from Cellini's painting itself that is stored in the Louvre how the statue of Juno looked and we know almost nothing about other statues, only few mentions of them remained. It happened to the statue of Jupiter that was however cast in silver, by its size it was a little more then he king's height, i.e. almost $2 \mathrm{~m}$ as described by the foreign diplomatist (Avery, 2000). It has not reached our days like most works embodied in precious metals and with the passage of time melted.

Cellini's work aroused a keen interest and François I, Marguerite de Navarre, duchess d'Etampes, cardinal de Lorraine, Henry II, the king of Navarre, dauphin and dauphine - Henry II and Catherine de Medici were among his manufactory visitors. François' I famous ceremonial salt-cellar kept in the Vienna Museum of Art History was the most well-known order made in France. Gold and multicolored enamels were used to create this salt-cellar, this is master Benvenuto's the only work from precious materials (except medals) that has survived to these days.

«The Nymph of Fontainebleau» relief was one of Cellini's first works for Fontainebleau, now decorating the Louvre stairs and previously located in the tympan above the door, «Porte Dorée». Initially it was intended for Fontainebleau, but when the master left for Italy in 1545 and the king died 2 years later it was placed due to F. de l'Orme's decision above the castle of Anet gates. This is an allegorical image with a very clear subtext. The royal favorite - the duchess d'Etampes was the Fontainebleau nymph and the deer was one of Francis' emblems. The master placed the salamander above the relief - the king's ones as well. The high relief is made of bronze. The relief is possible to have being created not only by Cellini himself but also by a group of other masters, P. Bontems was among them. The deer figure located next to Diana was deformed during the French Revolution, because the deer image was perceived as the hunting right symbol belonging only to the nobility.

Orazio Gentileschi also had a French period but it became very short in time - from 1624 to 1626 so it is difficult to talk about the artist's contribution to the renewed French art formation. The painting commissioned by Queen Mary for the Luxembourg Palace dates by this period in the 
Julia Romanenkova \& Halyna Kuzmenko \& Ivan Bratus \& Olha Konovalova. Traditions synthesis as Fontainebleau style international character foundation in French art of the XVI century

decoration of which numerous masters contributed, among whom P.-P. Rubens was. «Happiness Conquering Danger» (1624 - 1625).

II mid of XVI century is a period for French art when Italian influence is inferior to the northern one, first of all to Flemish. The artists who come most often from Antwerp or Amsterdam have been playing the main role from now. At this time the School became «the Mannerist trend for the Nordic countries conductor» (Petrusevich, 2000: 214) i.e France turns from a follower into a master. The artists getting to Fontainebleau, create their works under the First School representatives direct influence, learn on Rosso and Primaticcio's works. Their activities most often did not extend beyond the residence lines, although they influenced what was happening around. That is why the Second School is a much more closed phenomenon focused on itself. The change processes are very active, but INSIDE the School phenomenon itself. The Flemings created the art of France, learning from the French and Italians, creating the Italian and French traditions synthesis with a Flemish touch.

T. Dubreuil, A. Dubois and M. Freminet were the French art Flemish branch epoch core. Toussaint Dubreuil's mention can be found in the period from 1561 to 1602. The master's biography is assumed to have included a trip to Italy. He was engaged in both frescoes and easel paintings, graphics. Dubreuil is known most often to have done only preparative cartoons for his frescoes but the other artists transferred them into pictures. Dubreuil might have been Ruggiero da Ruggieri's follower and Martin Freminet's father's one. First of all the paintings in SaintGermain-en-Laye, in the Fontainebleau castle the Poets hall, the Apollo gallery half of the arch (instead of the one burned down in 1561), where the second part was painted by Jacob Bunel, should be mentioned. Dubreuil only managed to arrange the composition, leave the general scheme on the arch and suddenly died. Contemporaries called this work «gigantomachy» because it was an allegorical figure of Henry IV in the form of Jupiter striking the giants. Working in the Fontainebleau castle Poets hall Dubreuil created 14 compositions there illustrating Heracles story. According to some researchers (S. Beguin) he worked on «Heracles story» together with Ruggieri, however the works were made by Dubreuil himself according to the castle of Fontainebleau catalogues, the names of other masters are not mentioned. (List No. F. 1989.4). Unfortunately almost all these frescoes have disappeared. The scientists claim «Achilles and Chiron» to be the only fresco completely made by Dubreuil in the Poets hall painted under the First School art certain influence. The French Dumais, Onne, Poisson, the Flemish Thierry Aertsen were among the master's fellows who realized his ideas, which were embodied in paintings and cartoons. They decorated (according to his paintings) the Small Gallery of the Louvre where they worked together with Jacob Bunel and his wife Margarita Bausch in 1601, as later in Saint-Germainen-Laye but the works were not completed due to sudden Dubreuil's death in 1602. However according to the Fontainebleau castle museum staff attribution, the fresco «Young Heracles Learning Archery» was also painted personally by Dubreuil (inv. no. F. 1989.4). 
Julia Romanenkova \& Halyna Kuzmenko \& Ivan Bratus \& Olha Konovalova. Traditions synthesis as Fontainebleau style international character foundation in French art of the XVI century

Dubreuil's oeuvre in the field of easel painting is also poorly known, as well as its graphics. These are the canvases «The Awakening of A Lady», 5 scenes from «Franciade» by de Ronsard, a poem about the mythic Hector's son who had escaped from Troy, stayed in France and became the French kings dynasty ancestor, «Angelica and Medoro» on the subject from «Raging Roland» (canto IX).

Ambroise Dubois is supposed to be one of the least explored personalities in the history of both French and Flemish Mannerism epoch. The few that are known about his biography are taken from A. Felibien's description. The great majority of works due to which we can get an idea of Dubois' creative career, was executed by him in the castle of Fontainebleau. Ambrosius Bosschaert might have been born in 1543 in Antwerp. His career has been traced only since 1595. Felibien writes he died at the age of 72 in 1615 (or of 71 years old, in 1614) in Fontainebleau. «The Siege of Amiens» from the western wall of the Ulysses Gallery in the castle of Fontainebleau is one of the first master's documented works there (not survived). Gabrielle d'Estrées' portrait was created for the Poets hall in the castle in1599. A similar portrait is kept in the castle of Chenonceau. Later Dubois carries out the castle of Fontainebleau main interior decoration. From 1600 to 1601 he is decorating the gallery of Diana, from 1601 to 1605 -is working on the Queen's cabinet design, from 1609 to 1610 - on the King's cabinet. And from 1612 his work is related to the chapel of Saint-Saturnin. In 1613 Dubois has already working in the Queen's cabinet in the Louvre. It seems possible to judge the Diana Gallery only by documents which are dissonant for the majority part («The Historical Description of Fontainebleau» by Gilbert in 1731, "Queen's Gallery, called the Gallery of Diana in Fontainebleau» 1858), because the paintings have not been survived to this day. After the Gallery destruction in 1810 some fragments were transferred to the canvas and placed by Louis Philippe's order in another Fontainebleau gallery -the Fresco Gallery (now Galerie dés Assiettes). The artist created this mural on the gesso by oil. There are mythological scenes and figures, allegories, royal portraits, landscapes, monograms are placed in the arch decorated with wooden panels as in the Ulysses Gallery. All this was accompanied by decor in grotesque manner. The wall cladding was partly decorated by woodcarvers and partly the walls were painted. The paintings motifs completely corresponded to the spirit of Mannerist painting: ornaments, bouquets of flowers, gilded elements on a pink background. Fresco upper part was surrounded on its sides by large polychromic compositions -by 12 mythological and 10 battle scenes dedicated to Henry's IV military feats. Smaller compositions are gods images. There was king figure in the image of Mars on the eastern wall, next- Marie de Medici's portrait in the guise of Diana. Queen's cabinet or Clorinda's one was the second of Fontainebleau castle interiors where Dubois worked. The date of its decor creation might be 1606, there were compositions created for the scenes from T. Tasso's works in this cabinet. «Jerusalem Delivered»). The hall was very much changed during the time of Louis XV.

The oval hall was later called the Salon Louis XIII. Its interior was decorated at the end of Henry's IV epoch and in the first years of his son reign, when Louis XIII was still little. Not all elements of this hall were made by Dubois. He is attributed to plafond depicting Theagenes and Chariclea, the

SCRIPTA, Revista internacional de literatura i cultura medieval i moderna, núm. 17 / juny 2021 / pp. 86-103 ISSN: 2340-4841 · doi:10.7203/SCRIPTA.17.18661 
Julia Romanenkova \& Halyna Kuzmenko \& Ivan Bratus \& Olha Konovalova. Traditions synthesis as Fontainebleau style international character foundation in French art of the XVI century

medallions near the fireplace, probably allegories of the dauphin birth, the images of Apollo and Diana, Heracles and Deianira. Dubois created 15 compositions in the Oval hall dedicated to the history of Theagenes and Chariclea, 11 of which have survived to this day.

Dubois also addressed to contemporary for him events, the fresco «Amiens Storm» proofs it -a battle scene from Henry's IV life where images of Gabrielle d'Estrées, Marie de Medici with white and red lilies, Marie de Medici in Diana's figure, Henry IV in the figure of Mars (although researchers sometimes hesitate regarding this work authorship), an allegorical depiction of the Painting art, Flora. Once the master addressed to self-portrai - this is a fragment of the second fresco from the series about Theagenes where he portrayed himself in a modern suit.

A. Dubois' groups of works illustrating literary and religious subjects can be highlighted separately. First of all these are 2 works in the upper chapel of Saint-Saturnin in Fontainebleau, «Trinity» and «The ascension of Christ», created in 1612, the second one under Louis XIII was embodied by Jean Dubois and Jean Doet according to his son's design.

In 1601 Henry IV began new work on Conciergerie's decor having invited Dubois for it. «Amiens Storm» from the Ulysses gallery in Fontainebleau, «The Justice of Paris» in 1601 and 3 more frescoes commissioned by the king: «Adam and Eve in the Garden of Eden», «Original Sin» and «The Expulsion of Adam and Eve from the Garden of Eden» are usually remembered in the conversation context about artist's lost works.

Since Dubois left Antwerp at the age of 25, his creative manner formation occured during his stay in the north. The manner was influenced by the Antwerp masters, second generation novelists. There is the name of Marten de Vos among them, 10 years elder to Dubois, who had passed the School of Italy, made a trip there and returned in 1558. This is one of the factors contributing to Dubois' creative development. Directly Italian influence is another factor. The artist took a lot from the main representatives of the Fontainebleau First School -Primaticcio and Niccolo dell'Abbate, studied on the Ulysses gallery example, having created its alikeness in the Diana gallery. However despite Flemish, Italian and French traditions synthesis the researches still consider A. Dubois' style, his touch to be individual. The desire for the arts synthesis, organic mutual enrichment and the various national cultures interaction, which was most characteristic for the Second School Flemish masters art, can be considered to be one of the main distinguishing features of the Second Fontainebleau School, catched Dubois' work up.

Another artist who can be considered to be one of the three founders of the Second School of Fontainebleau is Martin Freminet. It is known very little about him like about T. Dubreuil. 16 years, almost all his youth, he spent in Italy. Thus while A. Dubois brought primarily Flemish traditions into French art then the Flemish by origin Freminet became a «bringer» primarily of Italian influences. There is an assumption that Freminet was not a Flemish but a Frenchman (BEGUIN). He studied and worked in Rome since 1587 (according to some versions - from 1592), and in 1603 he was called 
Julia Romanenkova \& Halyna Kuzmenko \& Ivan Bratus \& Olha Konovalova. Traditions synthesis as Fontainebleau style international character foundation in French art of the XVI century

by the king to France, however before this French period starting, the artist managed to visit Venice and Turin, where he was in service of the duke of Savoy, Charles-Emmanuel I for a short period. Freminet's life French page was primarily associated with the design of the Trinity Chapel in Fontainebleau commissioned by Henry IV. The start date of these works is disputable -1605 or 1608. French researchers are inclined to believe that in 1605 Freminet was officially invited to fulfill this commission and on the $1^{\text {st }}$ of May, 1608 he already actually started its implementation. At the time of the $20^{\text {th }}$ of August of that year the Annunciation scene was almost completed. Since 1613 after Henry's IV death, the sculptor B. Tremble began to decor the chapel 14 scenes from Freminet's works that indicates the painting to have been already completed at that time. In 1619 the master suddenly died. His work was influenced by Italian Mannerism, Fontainebleau First School masters. Holy Trinity Chapel program is unique to French art, this is Freminet's life main work. He worked on it until his death with some intervals and finished it already under Louis' XIII reign. The arch frescoes main subject is the vicarious sacrifice for the sake of man salvation motif. «Noah's vision of God how he leaves the ark», «The Fall of the Rebel Angels», temperaments allegories -sanguine (air), phlegmatic (water), melancholic (earth) etc are among the main subjects. The composition «Christ in the Judgment day surrounded by seven major virtues» was chapel's ceiling main scene. Thus it was a kind of both the Old and New Covenant Books plots synthesis. A. Dubois' son, Jean Dubois, who created the Holy Trinity also worked the same chapel altar.

Two more cycles of M. Freminet's works «Four Fathers of the Church» and «Four Evangelists» might also have been created for the Fontainebleau chapel. These cycles remained incomplete due to master's death. And later cardinal de Richelieu bought these works for his castle near Ludon in Poitou. Framinet's picturesque style can be said mainly due to 6 sketches for the chapel window openings compositions. Henry's III courtyard, tending to pomp and panoply, turned into the simpler, of Henry's IV ascetic one; but after his falling in 1610 variegation returned again with Louis XIII. These changes also explained the change in the visual arts trends.

François Dubois is among the local masters in whose work there were periods when they created outside of France. Very little is known about him, only one picture can be a judgment of his work «St. Bartholomew's Day massacre» which is stored in the cantonal museum of Lausanne (No. 5762). But in this context, mention of it is appropriate because Dubois, originally from Amiens, spent his last years in Geneva (until his death in 1584), where he went because of his religious beliefs after Bartholomew's night events. It is only known from this work history that the Lyonese banker Jean Purna commissioned it to the master. It was created between 1572 and 1584 . The work diameter is $46 \mathrm{~cm}$, it is painted on oak. Chronologically it dates back the First School period. This canvas can be considered to be a kind of unique because it was painted by Protestant author opposite to official art. Researchers point to medieval traditions and the French «primitives» influence on F. Dubois' creative work. This picture can be considered to be not only a work of painting but also a valuable historical document, a chronicle, as well as Paris architecture history memorial. 
Julia Romanenkova \& Halyna Kuzmenko \& Ivan Bratus \& Olha Konovalova. Traditions synthesis as Fontainebleau style international character foundation in French art of the XVI century

\section{Conclusions}

In addition to the above-mentioned masters there are a lot of so-called the School of Fontainebleau anonyms, whose work also had a significant influence on the style formation. The School's graphics were also very characteristic the style nature understanding but at that time it was still auxiliary, so it was beyond the scope of attention in this article. The School of Fontainebleau was formed due to Italian, French and Flemish traditions synthesis, it had as its basis both Gothic traditions reminiscences and already transformed Renaissance influence, its international character was based on the Italian foundation, firstly enriched with local traditions and then northern ones. In a lot of ways the Fontainebleau style became the Baroque one precursor, giving it exaltation, pretentiousness, verboseness and compositions complexity as the external attributes leading features. But the style internal filling main features with the Baroque spreading will be lost - its desire to imitate, despair, hopelessness, escapism. Baroque will already be saturated with internal dynamics, movement, passion instead of coldness, exhaustion, courtesy and Mannerism deliberateness including its French local version. 
Julia Romanenkova \& Halyna Kuzmenko \& Ivan Bratus \& Olha Konovalova. Traditions synthesis as Fontainebleau style international character foundation in French art of the XVI century

\section{References}

Avery, Ch. (2000) Cellini's Silver Statues of the Gods for Fontainebleau: Materials of symposium in celebration of the 500 th anniversary of the birth of Benvenuto Cellini 3 November 1500 [Benvenuto Cellini. Artist, artisan, author], (New York, 28 October, 2000). New York, 2-14

Béguin, S. (1960) L'École de Fontainebleau, le maniérisme à la cour de France. Paris: Gonthier-Seghers

- (1984) French drawing of XVI century. Moscow: Izobrazitelnoye iskusstvo

—. (1973) Art of Nothen Renaissance. Moscow: Iskusstvo

Châstel, A. (1959) Art et humanisme a Florence au temps de Laurent de Magnifique: These pour la doctorat. Paris: Presses universitaires de France

—. (1995) L'Art Italien. Paris: Flammarion

—. (1968) La crease de la Renaissance. 1520-1600. Genève: Skira

- (1983) The sack of Rome. Princeton: Princeton university press

—. (1964) La peinture française de Fouquet à Poissin. Genèeve: Skira

Ehrmann, J. (1986) Antoine Caron. Paris: Flammarion

Fontainebleau. Art in France. 1528-1610: [Catalogue of exhibition, the National Gallery of Cahada]. V. 1. Ottawa, 1973.

Fontainebleau e la maniera Italiana. Mostra d'oltremare e del lavoro Italiano del mondo: [cat. exp.]. Roma, 1952

Frienländer, W. (1957) Mannerism and Anti-Mannerism in Italian Painting. New York: Columbia University Press

Hauser, A. (1968) Mannerism: The Crisis of the Renaissance and the Origin of Modern Art. 1 vol. London: Routledge \& Paul

L'art maniériste, formes et symbols. 1520-162: Catalogue d'exposition, Rennes, Musée des beaux-arts] (1978). Rennes: Musée des beaux-arts

L'École de Fontainebleau (1972) Paris: Éditions des Musées Nationaux

Le triomphe du Maniérisme Européen de Michel-Ange an Greco: Catalogue du Seconde Exposition sous les auspices du conseol de l'Europe, Rijksmuseum. Amsterdam, 1955. p. 54-57

Lévêque, J.-J. (1984) L'École de Fontaibnebleau. Neuchâtel: Éditions Ides et Calendes

Panofsky, D. et E. (1992) Étude iconigraphique de la Galerie François Ier a Fontainebleau. Paris Gérard Monfort

Petrusevich, N. (1973) Art of France of XV-XVI centuries. Leningrad: Iskusstvo

SCRIPTA, Revista internacional de literatura i cultura medieval $i$ moderna, núm. 17 / juny 2021 / pp. 86-103 
Julia Romanenkova \& Halyna Kuzmenko \& Ivan Bratus \& Olha Konovalova. Traditions synthesis as Fontainebleau style international character foundation in French art of the XVI century

Romanenkova, Y. (2003a) Painting of French representatives of the First School of Fontainebleau. Traditions and innovations in higher architecture and art education. Vol. 3-4, 2004; 1-2: p. 74-78

(2003b) Historical-political and cultural aspects of the prerequisites for the emergence of the national version of Mannerism in the culture of France of the XVI century. Traditions and innovations in higher architectural and artistic education. Vol. 1-2: p. 26-30

. (2011) School of Fontainebleau in the context of French art of the XVI century. Kiev: NARKKII

SCRIPTA, Revista internacional de literatura i cultura medieval $i$ moderna, núm. 17 / juny 2021 / pp. 86-103 